\title{
Agricultural abandonment and resilience in a Mediterranean periurban traditional agroecosystem: a landscape approach
}

\author{
María Vallés-Planells $^{1}$, Francisco Galiana ${ }^{1}$ and Ignacio Díez Torrijos $^{2}$
}

\begin{abstract}
Traditional cultural landscapes are experiencing strong changes. Abandonment is one of the most significant processes, especially since the last decades of the 20th century. From a resilience approach, it is believed that the preservation of these landscapes depends on their capacity to adapt to new challenges without altering their essential characteristics. Here, we assess the resilience of a traditional periurban agricultural landscape, Huerta de Valencia during the period 2008-2013, and use landscape character areas (LCAs) to allow a more comprehensive understanding of the spatial dimension of resilience. Our main goals are: (1) to estimate two dimensions of resilience of agricultural activity (persistence and adaptability) in the different LCAs that compose Huerta de Valencia, and (2) to analyze correlations between these two dimensions and a set of factors that may explain resilience behavior in Huerta de Valencia. Our results show the existence of different behavior patterns within the set of LCAs concerning resilience and suggest the importance of the initial landscape condition in terms of abandonment, land use, type of crop, and extent of people-place connection in promoting persistence. Regarding adaptability, transformation processes are more evident in areas showing a higher rate of abandonment because reversion of abandonment to irrigated arable land is the most frequent process of change in crop management. Lessons have emerged from our study of Huerta de Valencia that could be applied to other traditional periurban landscapes. To improve resilience, change should be guided toward farm types with high levels of flexibility that facilitate adaptation, encouragement of fulltime professional farming, and rise of the visibility of local varieties that are distinctive to the area. In addition, linkages between people and the physical space should be encouraged by the improvement of physical and visual connections that increase social use and appreciation of these traditional landscapes.
\end{abstract}

Key Words: adaptability; Huerta de Valencia; land-use change; landscape character; persistence; Spain

\section{INTRODUCTION}

Mediterranean traditional cultural landscapes can be defined as pre-18th century landscapes that have evolved slowly over the centuries. They are the result of coherent relations between the physical environment and local cultural adaptation that last for generations for the people living there (Antrop 1997). However, these landscapes are experiencing rapid and profound changes. In particular, land abandonment represents one of the major trends, especially since the last decades of the 20th century (Van Eetvelde and Antrop 2004, Plieninger et al. 2014, Lieskovský et al. 2015). The preservation of these landscapes is essential not only for their natural, cultural, and aesthetic values but also for the wealth of accumulated knowledge and experience in their management and use of natural resources.

International initiatives to safeguard these landscapes have emerged, such as the global partnership initiative on conservation and adaptive management of Globally Important Agricultural Heritage Systems launched by the Food and Agricultural Organization of the United Nations during the World Summit on Sustainable Development (Johannesburg, South Africa) in 2002. This initiative approaches the conservation of traditional landscapes from a resilience perspective. It assumes that the preservation of traditional landscapes depends on the capacity to adapt to new challenges without losing biological and cultural wealth and productive capacity. Moreover, it suggests the idea that traditional agroecosystems have the potential to provide solutions to the unforeseeable changes and transformations facing humanity in an era of climate change, energy, and financial crises (Koohafkan and Altieri 2011).
The resilience framework has been shown to be a useful approach for understanding the dynamics of cultural landscapes and identifying successful strategies that improve the capacity to adapt to change without losing the inherent values of those landscapes (Plieninger and Bieling 2013). Resilience assessments have been widely applied in a number of settings at different scales with different approaches involving different fields of knowledge and actors (O'Connell et al. 2015, Folke 2016, Quinlan et al. 2016). With regard to the variety of disciplines involved in resilience, Plieninger et al. (2015) suggest six areas in which landscape research may contribute to understanding the dynamics of socialecological systems. One of these areas is the consideration of landscape characterization methods to take into account the influence of landscape character in resilience assessments. Cumming (2011), Cumming et al. (2013), and Wu (2013) also suggest the need to include the explicit consideration of the spatial dimension in resilience assessments, both in terms of the composition and spatial arrangement of landscape elements. However, the explicit incorporation of landscape pattern and configuration in resilience works is still rare (Martín-López et al. 2017).

Traditional landscapes may be composed of different character areas (Swanwick and Land Use Consultants 2002) that share the same landscape structure but show different resilience behaviors because of differences in composition related to their immediate geographical and social context. To preserve these landscapes, it is important that a sufficient area, not just a relict, is kept that is representative of the whole system. Hence, it is important to understand what the most resilient areas are and what spatial properties enhance resilience. 
We aim to assess the resilience of a traditional historical cultural landscape, Huerta de Valencia, integrating its spatial dimension with the aid of landscape characterization methods. Our objectives are: (1) to estimate two dimensions of resilience of agricultural activity (persistence and adaptability) in the different landscape character areas that compose Huerta de Valencia, and (2) to analyze correlations between these two dimensions and a set of factors that may explain resilience behavior in Huerta de Valencia.

\section{STUDY AREA}

Huerta de Valencia is one of the six huerta landscapes left in Europe (Stanners and Bourdeau 1995). It contains the irrigated land surrounding the Valencia metropolitan area (Fig. 1). It is the result of a long-lasting human interaction with the physical environment; its origins as a huerta landscape are dated to the eighth century with the arrival of the Muslim tribes in Spain and the construction of the eight main Turia River irrigation channels (Guinot Rodríguez 2008). This landscape possess cultural values linked to the hydraulic and architectural heritage and immaterial goods such as traditional knowledge and institutions (e.g., Valencia Water Court, or Tribunal de las Aguas).

Fig. 1. Map of the study area location, landscape character areas in Huerta de Valencia with their corresponding codes, and sampling points for the social survey.

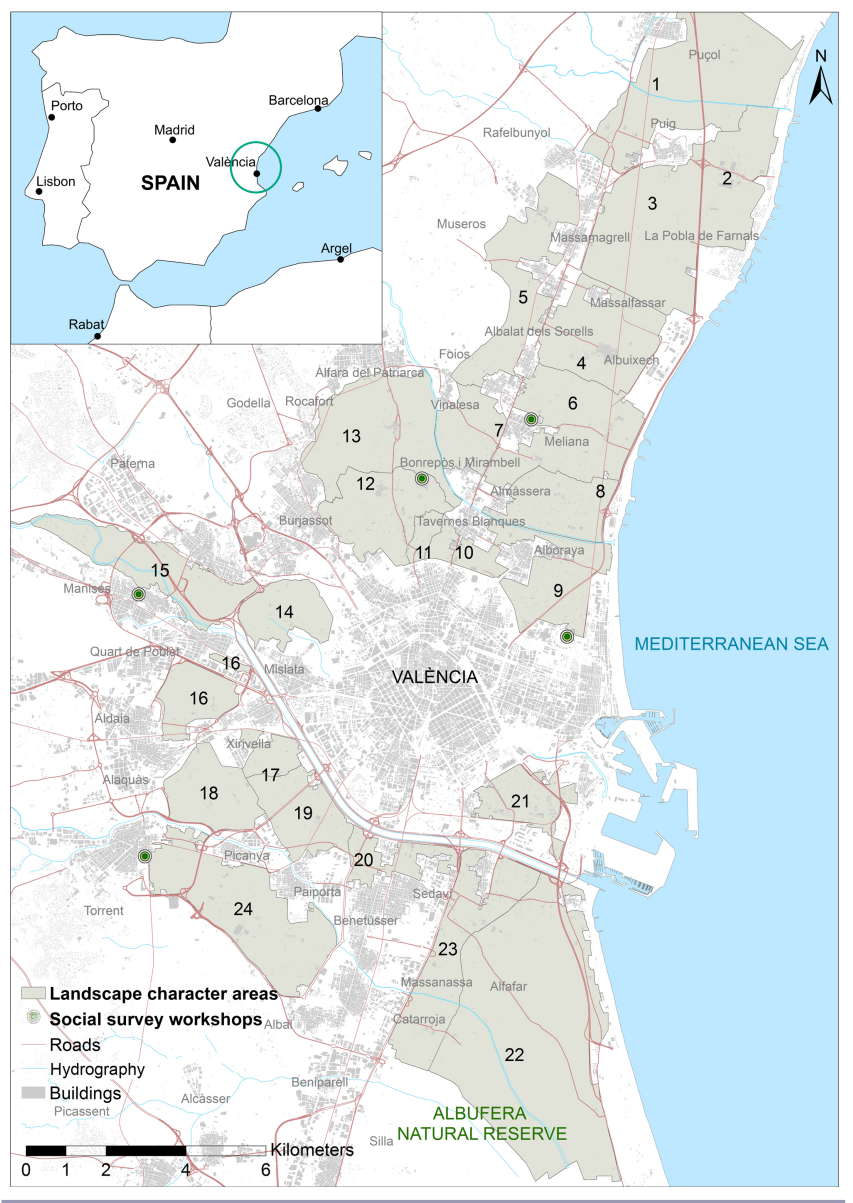

During the second half of the 20th century and the beginning of the 21 st century, Huerta de Valencia, similar to other traditional European landscapes (Van Eetvelde and Antrop 2004), experienced unprecedented rapid and profound changes. These changes resulted in a strong reduction in cultivated land cover. In $1950,10 \%$ of the historical Huerta had disappeared, and by 2006 , there was already a loss of $30 \%$ of area (Muñoz Criado 2009). Two factors contributed to this loss. First, urban areas have replaced the agricultural landscape, decreasing the area of Huerta, and new infrastructure has crossed over the Huerta landscape without considering the existing geographical patterns. Similar to other Mediterranean agricultural landscapes located in metropolitan areas, urban structures surrounded and fragmented the agricultural system. Second, the low profitability of agriculture has led to the abandonment of farming activity and the deterioration of cultural heritage.

Currently, because of the economic crisis, there has been a decrease in the pace of urban and infrastructure growth. Nevertheless, problems related to the low profitability of agriculture persist and, hence, so does the threat of Huerta abandonment. In 2013, the Valencia region was one of the regions in Spain with the highest rate of abandonment (Ministerio de Agricultura, Pesca y Alimentación 2014).

Characteristics of Huerta de Valencia connected to resilience

Because resilience is a context-dependent property, most authors agree that no universal indicators of resilience can be defined. However, it is possible to identify a set of rules or general principles to guide social-ecological systems to resilience that are applicable across scales of time and space (O'Connell et al. 2015, Quinlan et al. 2016). In the field of agroecosystem resilience, these rules are generally connected to: the levels of diversity and heterogeneity and the maintenance of natural capital; the consideration of the role of regulating ecosystem services (e.g., soil and water regulation, habitat protection, or pest and disease control); the capacity of developing improvements and innovations concerned with agro diversity and natural capital; the preservation and exchange of local knowledge; and the adaptation capacity regarding social capital, including selforganization and social connectedness (Van Oudenhoven et al. 2011, Cabell and Oelofse 2012, Bergamini et al. 2013, Darnhofer et al. 2016).

Huerta de Valencia shows many of the abovementioned characteristics that make it a resilient system. It has traditionally been a diverse landscape that has adapted to the population needs and economy in each historical period (Díez Torrijos and Sanchis Ibor 2007, Sanchis Ibor 2013, Besó Ros 2014). Its periurban condition has allowed a close relation between farm production and Valencia City, which is reflected in traditional markets where farmers directly send their fresh products to retail stores and municipal markets. The persistence of traditional farming practices such as crop rotation and keeping fallow strips contributes to maintaining soil fertility, which allows three harvests per year.

A network of historical channels of Arabic origin (Glick 1970) irrigates Huerta de Valencia. The value of this irrigation system is twofold. First, it is important because of its sociocultural value. Water is distributed under a clearly defined set of rules devised by farmers that ensures equitable sharing of water resources and 
adaptation to drastic fluctuations in river flow. Farmers organized in irrigation communities have managed the water resources since medieval times. Nine of the ten communities meet in one of the oldest customary courts of Europe, Valencia Water Court (Tribunal de las Aguas; Ortega-Reig et al. 2014). Second, compared to other methods of irrigation, a traditional gravity irrigation system has environmental advantages (Pavón et al. 2015). It promotes aquifer recharge and the drainage of runoff water, especially when there are strong rainfall events, and provides a permanent water sheet, which favors the development of spontaneous vegetation on the channel edges and associated wildlife.

Other factors are opposed to resilience. Diversity in Huerta de Valencia has decreased, especially since the second half of the 20th century with the emergence of orange tree fields, which are less demanding in labor and allow part-time farming. The use of local varieties has also decreased during recent decades. They tend to be replaced by outside varieties, which apparently show advantages in terms of yield and disease resistance (Maroto Borrego 1994, 2013). Natural vegetation is relict. The loss of biodiversity has been particularly significant since the second half of the 20th century. The application of pesticides and the use of chemical fertilizers, the disappearance of most of the remaining noncrop habitats, and the conversion of dirt-sided irrigation ditches to sheer-sided concrete channels involved in agricultural intensification resulted in habitat simplification. Nonetheless, Huerta de Valencia still supports a rich bird assemblage, especially during the winter months, which is mainly connected to the fallow fields and orange groves (Murgui 2010).

Agricultural engagement is low because part-time farms prevail over fully professionalized farms (only $36 \%$ of farm holders are dedicated completely to agriculture). Generation replacement is also scarce $(>70 \%$ of farm holders are $>55$ years old, and $<2 \%$ are $<34$ years old). Farmer age, together with the high proportion of part-time farmers and data about holder education (only $4 \%$ have university or professional agrarian studies), suggest a low level of professionalization, which generally involves a low level of innovation (Generalitat Valenciana 2018a).

\section{METHODS}

\section{Landscape character areas}

We chose landscape character areas (LCAs) as the unit of analysis. LCAs are defined as discrete geographical areas of a particular landscape type that can be identified at a range of scales, from the national to the local scale. The delineation of LCAs is based in the identification of landscape patterns. Each LCA has a distinct pattern of elements (geology, landform, soils, vegetation, land use, field patterns, and human settlement) that make it different from the units that surround it (Swanwick and Land Use Consultants 2002). The LCA approach is related to the existing physiogeographic landscape classification approaches traditionally applied in land evaluation and more recently in landscape ecology, including cultural and perceptual aspects of the landscape (Van Eetvelde and Antrop 2007).

The division of the area of study into LCAs allows the spatial dimension to be incorporated in the assessment of resilience. Huerta de Valencia shares a common element, the irrigation system, which was the origin of this landscape and has remained for 12 centuries. However, land use evolution has been different along the different areas that compose Huerta de Valencia. Polyculture of the horticultural crops is the main feature that characterizes the vegetation in the northern areas located near Valencia City. This condition may be explained by the scarce presence of infrastructure and the fact that industrial development has been traditionally less important in this area. In contrast, the west and south areas in proximity to Valencia City, which have experienced a higher degree of industrial development since the 1960s and have a higher level of fragmentation by infrastructure, show a higher degree of abandonment. With regard to the citrus trees, they mainly prevail in the north and south areas close to the external boundaries of the Huerta. These sectors correspond to larger field sizes and areas with a higher degree of immigration and industrial development that have promoted part-time farming. Rice prevails in the south, which is connected to Albufera Natural Reserve.

LCAs (Fig. 1) were defined by the Territorial Action Plan for the Protection of the Huerta de Valencia following a regionalization or subdivision procedure with the aid of geographic information systems and aerial photograph interpretation (Muñoz Criado 2009). First, the urban boundaries that enclose the agricultural cover were delineated. Second, the area was split according to the pattern shaped by agricultural activity and settlement. Finally, a further subdivision was made according to agricultural management, considering the area managed by each irrigation community. In total, 24 LCAs were identified.

\section{Resilience analysis: persistence and adaptability of agricultural activity}

Resilience analysis is focused on farming activity because agriculture has been the main factor in shaping Huerta de Valencia during the previous centuries. Two dimensions of resilience are considered: persistence and adaptability. For each dimension, a series of indicators are measured. In addition, we evaluate eight factors to explore the way in which they affect persistence and adaptability (Table 1).

Persistence is understood as the ability to maintain farming activity. In Huerta de Valencia, for the specific period between 2008 and 2013, the main threat to the continuity of farmland activity has been abandonment. We evaluated two parameters related to land abandonment. Rate of abandonment refers to the percentage of abandoned land within a LCA in the last year (2013) of the considered period. Speed of abandonment is calculated, for each LCA, as the difference between the rate of abandonment in the baseline year (2008) and that in the last year (2013) of the period.

Adaptability refers to human actions that sustain development on current pathways. It is the capacity to implement deliberate change in anticipation of or in reaction to external stimuli and stress (Folke 2016). In this case study, it relates to the capacity to implement changes in crop management that imply the continuity of agricultural activity. Adaptability is measured using three indicators. Incidence of positive changes estimates, for each LCA, the proportion of land that has experienced changes that involve the maintenance of agriculture during the period 2008-2013. Incidence of positive changes breaks down into two variables: reversion (changes from abandoned to cultivated land) and conversion (changes of crop). Here, reversion refers to changes 
Table 1. List of variables linked to resilience that were included in the analysis.

\begin{tabular}{|c|c|c|c|c|}
\hline Variable & Spatial scale & Unit & Time & Source \\
\hline \multicolumn{5}{|l|}{ Persistence } \\
\hline Rate of abandonment in 2013 & $\begin{array}{l}\text { Landscape character area } \\
\text { Municipality }\end{array}$ & $\%$ & 2013 & Land-use map \\
\hline Speed of abandonment & $\begin{array}{l}\text { Landscape character area } \\
\text { Municipality }\end{array}$ & $\%$ & 2008-2013 & Land-use map \\
\hline \multicolumn{5}{|l|}{ Adaptability } \\
\hline Incidence of positive changes & $\begin{array}{l}\text { Landscape character area } \\
\text { Municipality }\end{array}$ & $\%$ & 2008-2013 & Land-use map \\
\hline Reversion to arable land & $\begin{array}{l}\text { Landscape character area } \\
\text { Municipality }\end{array}$ & $\%$ & $2008-2013$ & Land-use map \\
\hline Conversion to arable land & $\begin{array}{l}\text { Landscape character area } \\
\text { Municipality }\end{array}$ & $\%$ & 2008-2013 & Land-use map \\
\hline \multicolumn{5}{|l|}{ Factors linked to resilience } \\
\hline Rate of abandonment in 2008 & Landscape character area & $\%$ & 2008 & Land-use map \\
\hline Type of land use & Landscape character area & $\%$ & 2008 & Land-use map \\
\hline $\begin{array}{l}\text { Diversity of herbaceous crops } \\
\text { (Shannon diversity index) }\end{array}$ & Municipality & $0-3$ & 2008 & $\begin{array}{l}\text { Valencia Region Agriculture } \\
\text { Department }\end{array}$ \\
\hline Density of dwellings & Landscape character area & $\begin{array}{c}\text { dwellings/ha } \\
<0.1(1) \\
0.1-0.3(2) \\
0.3-0.7(3) \\
>0.7(4)\end{array}$ & 2008 & Topographic map \\
\hline Social use & Landscape character area & $\begin{array}{c}\text { Low (1) } \\
\text { Medium (2) } \\
\text { High (3) }\end{array}$ & 2008 & Social survey \\
\hline Level of forgottenness & Landscape character area & $\begin{array}{c}\text { Low (1) } \\
\text { Medium (2) } \\
\text { High (3) }\end{array}$ & 2008 & Social survey \\
\hline Social value & Landscape character area & $\begin{array}{c}\text { Low (1) } \\
\text { Medium (2) } \\
\text { High (3) }\end{array}$ & 2008 & Social survey \\
\hline
\end{tabular}

from abandoned to irrigated arable land, and conversion refers to changes from citrus to irrigated arable land, which are the major positive transformations in Huerta de Valencia.

To calculate these parameters, we used land-use maps from 2008 and 2013. The land-use map corresponding to 2008 was obtained from the work developed for the Territorial Action Plan for the Protection of the Huerta de Valencia (Muñoz Criado 2009). The land-use map corresponding to 2013 was developed by photointerpretation with the aid of ArcGIS software and the latest available aerial photograph $(50 \mathrm{~cm}$ resolution), which corresponded to a 2012 flight (Argyelan et al. 2015). A field survey was conducted during May 2014 on a sample area consisting of 500-m buffer zones around a set of randomly selected points that were spatially distributed among the 24 LCAs. According to the field survey, the estimated error of the land-use map in 2013 was $5.3 \%$.

Based on the literature on agro-ecosystem resilience indicators (van Oudenhoven et al. 2011, Cabell and Oelofse 2012, Bergamini et al. 2013, Darnhofer et al. 2016), a set of factors that conditions resilience and shows spatial variation within Huerta de Valencia was identified and analyzed within each LCA to understand their relationship to persistence and adaptability (Table 1).

First, we considered the rate of abandonment in 2008 as a measure of the rate of landscape degradation (van Oudenhoven et al. 2011). Degradation involves the loss of functionality of the different elements that compose this agroecosystem. Thus, the rate of abandonment is seen from two points of view in this work. It is a factor that conditions resilience when referred to the baseline year (2008) because it is assumed that the higher the rate of abandonment, the more vulnerable an agro-ecosystem is. In addition, as explained above, it is considered, together with speed of abandonment, as an estimation of persistence in 2013.

With regard to diversity, which is a recurrent indicator in resilience assessment (van Oudenhoven et al. 2011, Cabell and Oelofse 2012, Bergamini et al. 2013, Darnhofer et al. 2016), we considered three factors: type of land use, type of herbaceous crop, and diversity of herbaceous crops. Type of land use refers to the proportions of the main crop types (horticultural, citrus, and rice) in each LCA in 2008. It is derived from the 2008 land-use map. This variable is connected to the structural factor referred to by Darnhofer et al. (2016) as farm type. Type of land use provides a broad estimation of the diversity of a certain LCA because horticultural land use is usually more diverse than citrus and rice fields. Type of herbaceous crop refers to the proportions of the different types of herbaceous crops and is useful to identify the level to which local herbaceous crops are present within each LCA. Diversity of herbaceous crops is estimated using the Shannon diversity index (Shannon and Weaver 1964), which considers the number of herbaceous crops and their relative abundance in a certain LCA. 
Because the land-use map does not include data about the specific herbaceous crops that are grown in each LCA, we used the information about the cover of cultivated crops per municipality provided by the Valencia Region Agriculture Department. The use of these data implies a certain amount of error because there are municipalities that are not completely contained in Huerta de Valencia. However, the fact that most of their horticultural land belongs to Huerta de Valencia led us to use these data for the analysis. Consequently, type of herbaceous crop and diversity of herbaceous crops are not related to the LCAs, as are the other factors, but to the municipalities that are included in Huerta de Valencia.

Finally, we included four factors that are an estimation of connectedness (Cabell and Oelofse 2012) in terms of the relationships between people and the physical space: density of rural dwellings, social use, level of forgottenness, and social value. It is assumed that the higher the presence of physical and perceptual bonds with place, the higher place attachment and willingness to preservation is. Density of rural dwellings is an estimate of the physical accessibility of each LCA. Accessibility is not usually included in the general indicators of resilience, but it appears to be an important factor in the persistence of agricultural landscapes to abandonment (Lieskovský et al. 2014). Density of dwellings (dwellings/ha) classifies LCAs into four classes (Muñoz Criado 2009). Social use, level of forgottenness, and social value are perceived spatial attributes of LCAs related to the field of social landscape assessment (e.g., Brown 2004). The factor social use classifies LCAs into three classes according to the level of use expressed by the population. The factor level of forgottenness classifies LCAs into three classes according to the level of ignorance expressed by the participants. Finally, social value classifies LCAs into three classes according to the perceived value.

The social survey carried out to assess social use, level of forgottenness, and social value of the LCAs was part of the public participation process conducted during the Territorial Action Plan for the Protection of the Huerta de Valencia (Muñoz Criado 2009). This process was structured in five workshops distributed along Huerta de Valencia (Fig. 1) to ensure participation of all municipalities involved in the area of study. Each workshop aimed to include representative people from the following groups: local authorities, local technical staff, farmers, students, experts in topics connected to Huerta de Valencia, and environmental and neighborhood associations. Participants were directly invited by the local development agents from each municipality or through the web page created to provide information about the Territorial Action Plan. In addition, two experts in Huerta de Valencia were invited to each workshop. Approximately 40-50 people participated in each workshop (in all, 200 people). Workshops consisted of four activities, one of which was the assessment of LCAs. For this activity, a set of boards showing a map with the LCAs and a brief description were printed to allow participants to fill in a questionnaire about their relationship with the LCAs (Appendix 1).

\section{Data analysis}

Correlation analysis was carried out to examine the relationships between the two dimensions of resilience (persistence and adaptability) and the factors that are assumed to promote resilience using SPSS 16.1. Two correlation analyses were performed. The first analysis included the following factors: rate of abandonment in 2008, type of land use, density of rural dwellings, social use, level of forgottenness, and social value, all referred to the LCAs. The second analysis incorporated type and diversity of herbaceous crops, which were calculated for each municipality.

\section{RESULTS}

The analysis of land-use change between 2008 and 2013 indicates that the proportion of land abandonment has increased from 11.11 to $15.52 \%$ (Appendix 2). The increase in abandonment is mainly citrus and irrigated arable land $(30.50 \%$ and $9.45 \%$ of the total abandoned area, respectively; Appendix 3). When considering the different LCAs that compose Huerta de Valencia, the spatial heterogeneity of abandonment is evident. In 2013, the rate of abandonment ranged from $2.92 \%$ (LCA 8) to $41.01 \%$ (LCA 16; Fig. 2).

In contrast, positive changes affect only $4.61 \%$ of the total area, and the spatial variation is less significant, ranging from 0.28 (LCA 9) to $13.65 \%$ (LCA 18; Fig. 2). These changes (see Appendix 3) are mainly through the conversion of citrus land to horticultural fields and the reversion of abandonment to irrigated arable land $(57.22 \%$ or 299.8 ha and $27.66 \%$ or 144.9 ha, respectively, of the total area of 523.95 ha affected by positive changes). Conversion to other fruit trees is rare.

The most abandoned areas in 2008 are those with a higher level of abandonment in 2013, which reveals a positive correlation (0.928) between the areas abandoned in 2008 and 2013 (Table 2, Appendix 4). However, there is no significant correlation between the rate of abandonment in 2008 and the speed of abandonment. For instance, LCA 13, with a low rate of abandonment $(6.18 \%)$ in 2008 , increased in rate of abandonment by $9.61 \%$ (see Appendix 2 ). With regard to the parameters of adaptability, as expected, there are positive correlations between incidence of positive changes and reversion from abandoned to irrigated arable land with rate of abandonment in $2008(r=0.604$ and 0.800 , respectively; Table 2, Appendix 4).

The type of land use affects the proportion and speed of abandonment. The analysis of the data derived from the land-use map shows that the proportion of land covered by herbaceous crops is negatively correlated with the proportion and speed of abandonment ( $r=-0.503$ and -0.417 , respectively). In contrast, citrus fields are positively correlated $(r=0.704)$ with the speed of abandonment. Concerning the incidence of positive changes, there are no significant correlations with type of land use (Table 2, Appendix 4).

When looking at the data on the composition of herbaceous crops, we find that rate of land abandonment in 2013 is positively correlated with the proportion of artichokes $(r=0.412)$ and negatively correlated with tiger nuts $(r=-0.398)$. Incidence of positive changes and changes from citrus to irrigated arable land are positively correlated with ornamental plants $(r=0.492$ and 0.497 , respectively) and tiger nut is negatively correlated with incidence of positive changes ( $r=-0.344$; Table 3$)$.

The lack of correlation between the diversity of crops in 2008 and persistence and adaptability suggests that a higher diversity of crops is not related to more resilient behavior in this area (Table 
Fig. 2. Maps showing the rate and speed of abandonment and incidence of positive changes for the landscape character areas in Huerta de Valencia.

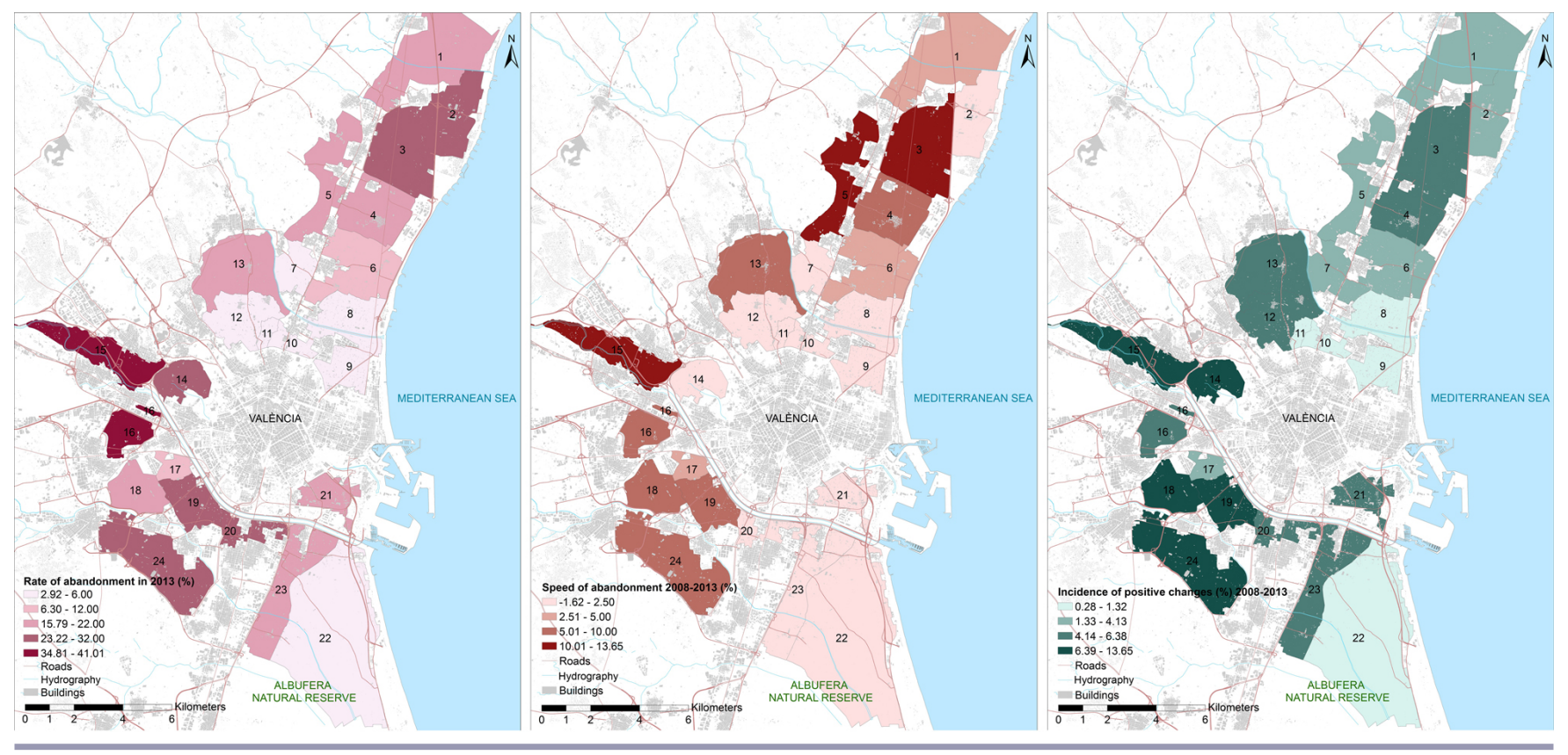

3). However, we also note that the diversity of herbaceous crops is low in Huerta. In 2013, 50 different crops were produced, but 8 crops (Appendix $5 \mathrm{~A}$ ) represented $74 \%$ of the area covered with herbaceous crops. On the verge of disappearance, $60 \%$ of the crops covered $<30$ ha $(1 \%$ of the area covered with herbaceous crops; Appendix 5B).

The density of dwellings follows a double gradient. It increases with proximity to Valencia City and to the coast (Appendix 6). The negative correlation between the rate of abandonment in 2013 and the density of dwellings $(r=-0.503)$ suggests that the more inhabited areas show a higher level of persistence. There are no significant correlations between density of dwellings and the incidence of positive changes (Table 2, Appendix 4).

Social perception is also heterogeneous throughout the Huerta. The areas located in the north, which are adjacent to Valencia City, and the area covered by rice fields, which is part of the Albufera Natural Reserve, show higher appreciation and public use by people. In contrast, in the areas positioned southwest of Valencia City, with higher levels of fragmentation, which causes the isolation of smaller cultivated patches, spatial references are scarce, and the Huerta seems to have disappeared from people's environmental image (Fig. 3). Those units with a high frequency of use are negatively correlated with rate of abandonment in 2013 $(r=-0.488)$ and reversion to irrigated arable land $(r=-0.409)$. Forgotten areas show a positive correlation with the rate of abandonment in $2013(r=0.462)$ and incidence of positive changes $(r=0.478)$. Finally, social value is negatively correlated with the rate of abandonment in $2013(r=-0.687)$, incidence of positive changes $(r=-0.426)$, and reversion from abandoned to irrigated arable land ( $r=-0.535$; Table 2, Appendix 4).
Finally, when analyzing the correlations between persistence and adaptability, we find positive correlations between rate of abandonment in 2013 with incidence of positive changes and changes from abandoned to irrigated arable land $(r=0.591$ and 0.697, respectively; Table 2, Appendix 4). This result shows that, in our case study, fewer changes regarding crop management are carried out in areas with higher persistence, in terms of less abandonment. Changes are a response to revert the abandoned condition of agricultural land or a reaction to the low profitability of existing citrus land.

\section{DISCUSSION}

The results show the spatial variation of resilience in Huerta de Valencia in terms of persistence and adaptability. The set of LCAs that compose Huerta de Valencia show different behavior patterns concerning resilience. Whereas the LCA located in Albufera Natural Park (LCA 22) and the areas north of Valencia City, with a predominance of irrigated arable land (LCAs 7-12), show a very low proportion of abandonment $(<6 \%)$, most of the other units show high rates of abandonment (between 15 and $25 \%$ ). These rates are even higher in certain areas, such as LCAs 15 and 16 , where the present rate of abandonment has reached $34.8 \%$ and $41 \%$, respectively. The results reveal the importance of the initial landscape condition in terms of abandonment, land use, type of crop, and the level of people and place connections in promoting persistence.

Concerning the influence of the existing condition, agricultural abandonment is more likely to occur in LCAs that were already showing a high rate of abandonment in 2008. This finding is consistent with those of previous authors (e.g., Levers et al. 2018), who suggest that neighborhood conditions may trigger the 
Table 2. Pearson correlations between factors that are assumed to promote resilience and the two dimensions of resilience (persistence and adaptability) with respect to landscape character areas. Abbreviations: Aab $=$ speed of abandonment, Ab08 $=$ rate of abandonment in 2008, Ab13 = rate of abandonment in 2013, Ab-hort = proportion of reversion to arable land, Citr08 = proportion of citrus in 2008, Citr-hort $=$ proportion of conversion to arable land, Hort $08=$ proportion of herbaceous crops in 2008 , Forgot $=$ level of forgottenness in 2008 , Positive $=$ incidence of positive changes, Ric $08=$ proportion of rice in 2008 , Use $=$ social use in 2008 , Value $=$ social value in 2008, Viv/ha = density of dwellings in 2008.

\begin{tabular}{|c|c|c|c|c|c|}
\hline \multicolumn{2}{|c|}{ Positive correlation } & \multicolumn{2}{|c|}{ Negative correlation } & \multicolumn{2}{|c|}{ No significant correlation } \\
\hline Variables & Correlation & Variables & Correlation & Variables & Correlation \\
\hline $\begin{array}{l}\text { Ab08 vs. Ab13 } \\
\text { Ab08 vs. Positive } \\
\text { Ab08 vs. Ab-hort } \\
\text { Citr08 vs. Aab } \\
\text { Forgot vs. Ab13 } \\
\text { Forgot vs. Positive } \\
\text { Ab13 vs. Positive } \\
\text { Ab13 vs. Ab-hort }\end{array}$ & $\begin{array}{l}0.928^{* *} \\
0.604 * * \\
0.800^{* *} \\
0.704^{* *} \\
0.462 * \\
0.478^{*} \\
0.591 * * \\
0.697 * *\end{array}$ & $\begin{array}{l}\text { Hort } 08 \text { vs. Ab13 } \\
\text { Hort08 vs. Aab } \\
\text { Viv/ha vs. Ab13 } \\
\text { Use vs. Ab13 } \\
\text { Use vs. Ab-hort } \\
\text { Value vs. Ab13 } \\
\text { Value vs. Positive } \\
\text { Value vs. Ab-hort }\end{array}$ & $\begin{array}{l}-0.580^{* *} \\
-0.417^{*} \\
-0.503^{*} \\
-0.488^{*} \\
-0.409^{*} \\
-0.687^{* *} \\
-0.426^{*} \\
-0.535^{* *}\end{array}$ & $\begin{array}{l}\text { Ab08 vs. Aab } \\
\text { Ab08 vs. Citr-hort } \\
\text { Hort08 vs. Positive } \\
\text { Hort08 vs. Ab-hort } \\
\text { Hort08 vs. Citr-hort } \\
\text { Citr08 vs. Ab13 } \\
\text { Citr08 vs. Positive } \\
\text { Citr08 vs. Ab-hort } \\
\text { Citr08 vs. Citr-hort } \\
\text { Ric08 vs. Ab13 } \\
\text { Ric08 vs. Aab } \\
\text { Ric08 vs. Positive } \\
\text { Ric08 vs. Ab-hort } \\
\text { Ric08 vs. Citr-hort } \\
\text { Viv/ha vs. Aab } \\
\text { Viv/ha vs. Positive } \\
\text { Viv/ha vs. Ab-hort } \\
\text { Viv/ha vs. Citr-hort } \\
\text { Use vs. Aab } \\
\text { Use vs. Positive } \\
\text { Use vs. Citr-hort } \\
\text { Forgot vs. Aab } \\
\text { Forgot vs. Ab-hort } \\
\text { Forgot vs. Citr-hort } \\
\text { Value vs. Aab } \\
\text { Value vs. Citr-hort } \\
\text { Ab13 vs. Citr-hort } \\
\text { Aab vs. Positive } \\
\text { Aab vs. Ab-hort } \\
\text { Aab vs. Citr-hort }\end{array}$ & $\begin{array}{c}0.241 \\
0.175 \\
-0.256 \\
-0.220 \\
-0.197 \\
0.357 \\
0.186 \\
-0.056 \\
0.291 \\
-0.265 \\
-0.273 \\
-0.249 \\
-0.186 \\
-0.162 \\
-0.360 \\
-0.285 \\
-0.093 \\
-0.162 \\
-0.103 \\
-0.288 \\
-0.118 \\
0.207 \\
0.350 \\
0.258 \\
-0.346 \\
-0.106 \\
0.257 \\
0.224 \\
0.074 \\
0.289\end{array}$ \\
\hline
\end{tabular}

occurrence of new abandonment patterns. For instance, some side effects of abandonment in Huerta de Valencia are an increase in insecurity and vandalism, the degradation of essential infrastructures such as irrigation diches, and the risk of pest proliferation.

Regarding land use and the type of crop, the correlation analysis suggests that the LCAs where vegetables prevail are more persistent than areas with citrus trees. This trend seems to continue during the subsequent years. According to the data on cultivated land in the counties corresponding to Huerta de Valencia (Generalitat Valenciana 2014, 2018b), the area of herbaceous crops has increased during the period 2013-2017 (79.51\% as compared to the data in 2013) while the area of citrus experienced a drop of $12.60 \%$ during the same period. There are different reasons that may explain this finding. First, herbaceous crops are more flexible than fruit trees. Whereas vegetable varieties can be changed easily from one year to the next, fruit trees are managed over at least 10 years (Darnhofer et al. 2016). The higher dependency of citrus trees on external inputs may also be a drawback for resilience (Bergamini et al. 2013). Second, farmer engagement is lower in the case of citrus fields because this crop, which is less demanding in labor, is linked to part-time farming. In addition, the decline in citrus prices has decreased interest in agrarian inversions, which were originally attractive because of their high profitability (Besó Ros 2014).

Citrus production has been affected by the European Union policies developed during the 21 st century, which have always encouraged market orientation and liberalization in fruits and vegetables. Financial support from the Common Agricultural Policy is of lesser importance for citrus compared to other agricultural products. Citrus production mostly relies on the Operational Programs for the Producers Organizations of Fruits and Vegetables, which are $50 \%$, cofinanced by producers' organizations and limited to a set of marked-oriented interventions. For the period 2008-2011, operational programs support just represented $1.5 \%$ of the total production value of fruits and vegetables in Spain (Universitat Politècnica de València and Ministerio de Agricultura Pesca y Alimentación 2012). However, the increasing presence of citrus from tertiary countries in the European Union markets, promoted by international trade 
Table 3. Pearson correlations between factors that are assumed to promote resilience and the two dimensions of resilience (persistence and adaptability) with respect to municipalities. Abbreviations: Aab = speed of abandonment, Ab13 = rate of abandonment in 2013 , $\mathrm{Ab}$-hort $=$ proportion of reversion to arable land, Arti08 $=$ proportion of artichoke in 2008, Cab08 $=$ proportion of cabbage in 2008 , Citr-hort $=$ proportion of conversion to arable land, Let08 $=$ proportion of lettuce in 2008, Oni08 $=$ proportion of onion in 2008 , Orn08 = proportion of ornamental plant in 2008, Positive $=$ incidence of positive changes, Pot08 = proportion of early potato in 2008 , Ric08 $=$ proportion of rice in 2008, SH08 $=$ Shannon diversity index in 2008 , Tig08 $=$ proportion of tiger nut in 2008, Wme08 $=$ proportion of watermelon in 2008 .

\begin{tabular}{|c|c|c|c|c|c|}
\hline \multicolumn{2}{|c|}{ Positive correlation } & \multicolumn{2}{|c|}{ Negative correlation } & \multicolumn{2}{|c|}{ No significant correlation } \\
\hline Variables & Correlation & Variables & Correlation & Variables & Correlation \\
\hline Arti08 vs. Ab13 & $0.412^{*}$ & Tig08 vs. Ab13 & $-0.398^{*}$ & Arti08 vs. Aab & 0.058 \\
\hline Orn08 vs. Positive & $0.492 * *$ & Tig08 vs. Positive & $-0.344 *$ & Arti08 vs. Positive & 0.027 \\
\hline \multirow[t]{43}{*}{ Orn08 vs. Cit-hort } & $0.497^{* *}$ & & & Arti08 vs. Ab-hort & -0.134 \\
\hline & & & & Arti08 vs. Cit-hort & 0.066 \\
\hline & & & & Ric08 vs. Ab13 & -0.186 \\
\hline & & & & Ric08 vs. Aab & -0.175 \\
\hline & & & & Ric 08 vs. Positive & -0.117 \\
\hline & & & & Ric08 vs. Ab-hort & 0.153 \\
\hline & & & & Rici08 vs. Cit-hort & -0.232 \\
\hline & & & & Oni08 vs. Ab13 & -0.233 \\
\hline & & & & Oni08 vs. Aab & 0.138 \\
\hline & & & & Oni08 vs. Positive & -0.118 \\
\hline & & & & Oni08 vs. Ab-hort & -0.139 \\
\hline & & & & Oni08 vs. Cit-hort & 0.042 \\
\hline & & & & Tig08 vs. Aab & 0.190 \\
\hline & & & & Tig08 vs. Ab-hort & -0.295 \\
\hline & & & & Tig08 vs. Cit-hort & -0.268 \\
\hline & & & & Cab08 vs. Ab13 & -0.091 \\
\hline & & & & Cab08 vs. Aab & 0.206 \\
\hline & & & & Cab08 vs. Positive & 0.012 \\
\hline & & & & Cab08 vs. Ab-hort & -0.087 \\
\hline & & & & Cab08 vs. Cit-hort & 0.057 \\
\hline & & & & Pot08 vs. Ab13 & 0.048 \\
\hline & & & & Pot08 vs. Aab & 0.057 \\
\hline & & & & Pot 08 vs. Positive & -0.072 \\
\hline & & & & Pot08 vs. Ab-hort & -0.237 \\
\hline & & & & Pot 08 vs. Cit-hort & 0.053 \\
\hline & & & & Let08 vs. Ab13 & 0.184 \\
\hline & & & & Let 08 vs. Aab & -0.023 \\
\hline & & & & Let08 vs. Positive & -0.045 \\
\hline & & & & Let 08 vs. Ab-hort & 0.135 \\
\hline & & & & Let 08 vs. Cit-hort & -0.062 \\
\hline & & & & Wme 08 vs. Ab13 & -0.223 \\
\hline & & & & Wme 08 vs. Aab & -0.119 \\
\hline & & & & Wme 08 vs. Positive & -0.198 \\
\hline & & & & Wme08 vs. Ab-hort & -0.177 \\
\hline & & & & Wme08 vs. Cit-hort & -0.112 \\
\hline & & & & Orn08 vs. Ab13 & 0.049 \\
\hline & & & & Orn08 vs. Aab & 0.199 \\
\hline & & & & Orn08 vs. Ab-hort & 0.079 \\
\hline & & & & SH08 vs. Ab13 & 0.119 \\
\hline & & & & SH08 vs. Aab & 0.002 \\
\hline & & & & SH08 vs. Positive & 0.108 \\
\hline & & & & SH08 vs. Ab-hort & 0.066 \\
\hline & & & & SH08 vs. Cit-hort & 0.137 \\
\hline
\end{tabular}

agreements, has increased market competition. In particular, there are seasonal overlaps between Valencia and tertiary countries citrus, especially for early season varieties of small citrus, which formerly had added value for their precocity, and also with other non-European Union northern hemisphere countries such as southern Mediterranean countries (Compés López et al. 2019).
The level of landscape protection and the use of local varieties accredited by certificates of origin may also explain the differences among the areas. There are just two crops with an appellation of origin: rice, connected to LCA 22, which is also part of the Albufera Nature Reserve, and tiger nut, grown in the northern areas adjacent to Valencia City. The results show that areas with a higher presence of rice and tiger nut show lower rates of 
Fig. 3. Maps showing the level of social use, social memory, and social value of the landscape character areas in Huerta de Valencia.

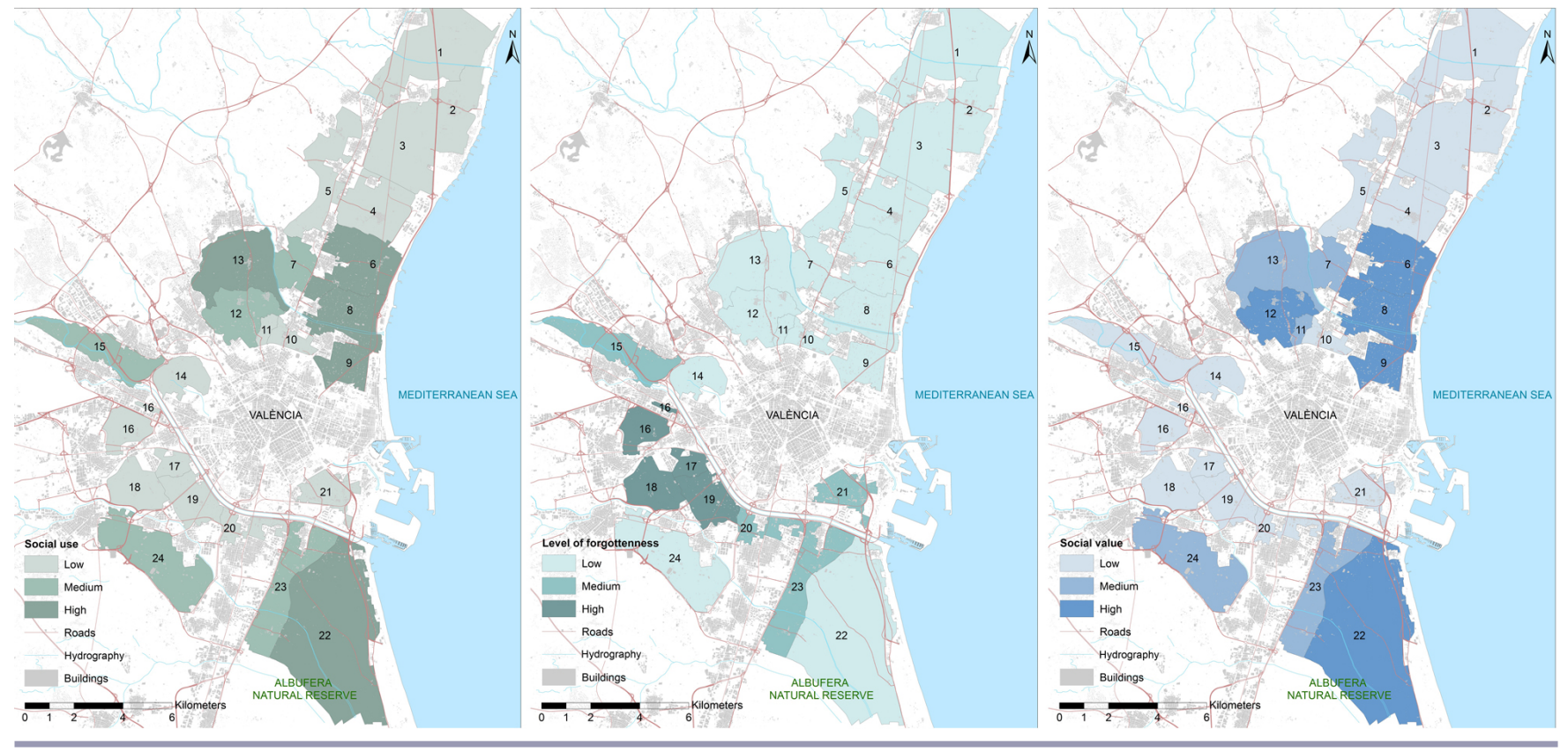

abandonment. This tendency persists. In particular, tiger nut has increased in cultivated area by $35.08 \%$ in the counties corresponding to Huerta de Valencia during the period 20032017 (Generalitat Valenciana 2014, 2018b).

The correlation between the density of rural dwellings and social appreciation with land abandonment reveals the importance of connections between people and place for landscape resilience (Walker and Ryan 2008, Selman 2012). The fact that the most persistent areas match with those showing more people-place connections in terms of physical access and perception indicates the essential role in landscape planning and environmental education for the provision of physical and social links that improve place attachment (Díez Torrijos 2012).

Concerning adaptability, the results indicate the existence of transformation processes in terms of reversion of abandonment or conversion to a different type of crop. These processes are more evident in the areas showing a higher rate of abandonment because reversion is the most frequent process of transformation. The area affected by the recultivation of abandoned land is not significant and does not make up for the loss of agricultural land due to abandonment, but it indicates the existence of a trend. This trend could be explained, in part, by the growth of farming initiatives that are developing alternative business models from conventional models, which make farming a viable source of income. In particular, Cerrada-Serra et al. (2018) outlined the emergence of initiatives in Huerta de Valencia led by young people who are motivated by new food business opportunities connected with organic and short food chains and who find farming to be a source of income and an unemployment response in the context of economic crisis. This phenomenon is common in other periurban spaces in southern Europe, as noted by Soulard et al. (2018). New entrants into farming are widely recognized as important to the ongoing vitality and competitiveness of the agricultural sector in rural regions in Europe (Piorr et al. 2018). In this way, entrepreneurship through alternative business models and new entrants into the agricultural sector are the focus of European initiatives (for instance, the Newbie network, "Future farmers in the spotlight", and The European Innovative Partnership on Agricultural Productivity and Sustainability).

It would be worthwhile to explore the profile of farmers and farming activities taking place in the identified recultivated areas and the type of factors that promote the reversion of abandonment by including local actors' perceptions. Another interesting area for further research would be working in the evolution of recultivation because the present political situation could encourage this phenomenon with the recent development of new policies and management tools for Huerta de Valencia. In particular, the recently approved Huerta de Valencia Law (Ley $5 / 2018$, de 6 de marzo, de la Huerta de Valéncia) and the Agrarian Development Plan (Generalitat Valenciana 2018a) emphasize abandoned plots and define mechanisms to promote the development of land tenancy agreements. This point is of special interest because the availability of abandoned land does not always imply access to the land (Cerrada-Serra et al. 2018).

\section{CONCLUSIONS}

We used LCAs to assess the spatial variation of resilience within a traditional Mediterranean landscape, Huerta de Valencia, considering the period between 2008 and 2013. Different behavior patterns of resilience have been inferred, especially regarding persistence. The heterogeneous distribution of abandoned land reflects different realities. In 2013, although on average $15.52 \%$ of land was abandoned across the whole area, $30.4 \%$ of the area showed a high level of stability, with $<6 \%$ abandonment. Concerning the level of adaptability, the proportion of land affected by the recultivation of abandoned land is of particular 
interest; although recultivation is not currently significant, it shows a trend that might be strengthened in the near future with the laws and tools recently approved by the regional government.

Several lessons can be learned from the Huerta de Valencia case study that might be useful for other periurban traditional landscapes. First, the higher persistence of areas where vegetables prevail and the trend for vegetables to be grown on abandoned land show two main points. The importance of maintaining a certain level of diversity of crops simultaneously involves different levels of flexibility and adaptation, which is exactly what characterized Huerta de Valencia until the second half of the 20th century, when certain areas became exclusively citrus land. Therefore, the same mistake should not be repeated by betting on a feasible monoculture in the short term that could lessen the system's resilience in the long term. However, the link between citrus land and part-time farming stresses the importance of the farmer-land connections and the need to increase full-time professional farming. Hence, it is necessary to provide mechanisms that facilitate access to land for full-time existing or new farmers and that improve farmers' professional development, emphasizing their business and social networking skills. Second, the fact that the most persistent areas correspond with crops that have certificates of origin indicates the importance of providing visibility to local varieties. The population should be aware of the added value of this quality and its role in preserving a traditional landscape. Third, the fact that the most persistent areas correspond to those showing more physical and social links indicates the importance of encouraging the maintenance and improvement of existing bonds between people, including farmers and urban dwellers, and the agricultural landscape.

Responses to this article can be read online at: http://www.ecologyandsociety.org/issues/responses. $\mathrm{php} / 11346$

\section{Acknowledgments:}

We thank Valencia Regional Agricultural Department for the data provided for this work, and in particular, Rafael Esteve.

\section{LITERATURE CITED}

Antrop, M. 1997. The concept of traditional landscapes as a base for landscape evaluation and planning. The example of Flanders region. Landscape and Urban Planning 38(1-2):105-117. https:// doi.org/10.1016/S0169-2046(97)00027-3

Argyelan, T., I. Díez Torrijos, M. C. Vallés Planells, and F. Galiana Galán. 2015. Land use change in Huerta de Valencia (2008-2013). Resilience and cultural landscapes. Pages 910-923 in C. SanchisIbor, G. Palau-Salvador, I. Mangue Alférez, and L. P. MartínezSanmartín, editors. Irrigation, society and landscape. Tribute to Tom F. Glick. Editorial Universitat Politècnica de València, Valencia, Spain. http://dx.doi.org/10.4995/ISL2014.2014.201

Bergamini, N., R. Blasiak, P. Eyzaguirre, K. Ichikawa, D. Mijatovic, F. Nakao, and S. M. Subramanian. 2013. Indicators of resilience in socio-ecological production landscapes (SEPLs).
United Nations University Institute of Advanced Studies, Yokohama, Japan. [online] URL: https://www.bioversityinternational. org/index.php?id=244\&tx news pi $\% 5$ Bnews $\% 5 \mathrm{D}=3686 \& \mathrm{cHash}=$ bd4a7efcb0f04f6645947574880a9e76

Besó Ros, A. 2014. La prolongació del verger. El paisatge dels horts de tarongers. Pages 46-47 in M. J. Picó Garcés and M. Ruiz Brox, editors. Veus per l'horta. Publicacions de la Universitat de València, Valencia, Spain.

Brown, G. 2004. Mapping spatial attributes in survey research for natural resource management: methods and applications. Society and Natural Resources 18(1):17-39. https://doi.org/10.1080/08941920590881853

Cabell, J. F., and M. Oelofse. 2012. An indicator framework for assessing agroecosystem resilience. Ecology and Society 17(1):18. https://doi.org/10.5751/ES-04666-170118

Cerrada-Serra, P., L. Colombo, D. Ortiz-Miranda, and S. Grando. 2018. Access to agricultural land in peri-urban spaces: social mobilisation and institutional frameworks in Rome and Valencia. Food Security 10:1325-1336. https://doi.org/10.1007/ s12571-018-0854-8

Compés López, R., J. M. García Alvarez-Coque, and V. D. Martínez Gómez. 2019. Informe sobre impacto del Acuerdo Comercial entre la UE y los países de la Comunidad de Desarrollo de África Meridional en relación con el sector citrícola. Estudio del caso valenciano. Impacto económico, social y territorial. Technical Report for European Parliament. Los Verdes/Alianza Libre Europea, .

Cumming, G. S. 2011. Spatial resilience: integrating landscape ecology, resilience, and sustainability. Landscape Ecology 26 (7):899-909. https://doi.org/10.1007/s10980-011-9623-1

Cumming, G. S., P. Olsson, F. S. Chapin III, and C. S. Holling. 2013. Resilience, experimentation, and scale mismatches in socialecological landscapes. Landscape Ecology 28(6):1139-1150. https://doi.org/10.1007/s10980-012-9725-4

Darnhofer, I., C. Lamine, A. Strauss, and M. Navarrete. 2016. The resilience of family farms: towards a relational approach. Journal of Rural Studies 44:111-122. https://doi.org/10.1016/j. jrurstud.2016.01.013

Díez Torrijos, I. 2012. La huerta de Valencia, estructura y paisaje. Palimpsesto 04. La permanencia del cambio. Cátedra Blanca, Universitat Politècnica de Catalunya, Barcelona, Spain.

Díez Torrijos, I., and C. Sanchis Ibor. 2007. Territorio e imagen. La percepción del paisaje de la huerta de Valencia. Saitabi 57:63-76. [online] URL: http://hdl.handle.net/10550/27280

Folke, C. 2016. Resilience (Republished). Ecology and Society 21 (4):44. https://doi.org/10.5751/ES-09088-210444

Generalitat Valenciana. 2014. Informe del sector agrario valenciano 2013. Generalitat Valenciana, Valencia, Spain. [online] URL: http://www.agroambient.gva.es/es/informes-del-sector-agrariovalenciano

Generalitat Valenciana. 2018a. Plan de desarrollo agrario de la huerta de Valencia. Conselleria de Agricultura, Desarrollo Rural, Emergencia Climática y Transición Ecológica, Generalitat 
Valenciana, Valencia, Spain. [online] URL: http://www. agroambient.gva.es/es/web/agricultura/novedades/-/asset_publisher/ cDoEgHxQ2gTH/content/plan-de-desarrollo-agrario-de-la-huertade-valencia

Generalitat Valenciana. 2018b. Informe del sector agrario valenciano 2017. Generalitat Valenciana, Valencia, Spain. [online] URL: http://www.agroambient.gva.es/es/informes-del-sector-agrariovalenciano

Glick, T. F. 1970. Irrigation and society in medieval Valencia. Harvard University Press, Cambridge, Massachusetts, USA. https://doi.org/10.4159/harvard.9780674281806

Guinot Rodríguez, E. 2008. El paisaje de la huerta de Valencia: elementos de interpretación de su morfología espacial de origen medieval. Pages 115-129 in Historia de la ciudad. V. Tradición y progreso. Icaro-Colegio Territorial de Arquitectos de Valencia, Universidad Politécnica de Valencia, Valencia, Spain.

Koohafkan, P., and M. A. Altieri. 2011. Globally important agricultural heritage systems: a legacy for the future. Food and Agriculture Organization of the United Nations, Rome, Italy. [online] URL: http://www.fao.org/fileadmin/templates/giahs/ PDF/GIAHS Booklet EN WEB2011.pdf

Levers, C., M. Schneider, A. Prishchepov, S. Estel, and T. Kuemmerle. 2018. Spatial variation in determinants of agricultural land abandonment in Europe. Science of the Total Environment 644:95-111. https://doi.org/10.1016/j.scitotenv.2018.06.326

Lieskovský, J., P. Bezák, J. Špulerová, T. Lieskovský, P. Koleda, M. Dobrovodská, M. Bürgi, and U. Gimmi. 2015. The abandonment of traditional agricultural landscape in Slovakia analysis of extent and driving forces. Journal of Rural Studies 37:75-84. https://doi.org/10.1016/j.jrurstud.2014.12.007

Lieskovský, J., P. Kenderessy, J. Špulerová, T. Lieskovský, P. Koleda, F. Kienast, and U. Gimmi. 2014. Factors affecting the persistence of traditional agricultural landscapes in Slovakia during the collectivization of agriculture. Landscape Ecology 29:867-877. https://doi.org/10.1007/s10980-014-0023-1

Maroto Borrego, J. V. 1994. Potencialidad y expectativas de la producción hortícola de primor en la huerta de Valencia. Pages 177-292 in P. J. Salvador Palomo, editor. Seminario internacional sobre la huerta de Valencia. Ayuntamiento de Valencia, Valencia, Spain.

Maroto Borrego, J. V. 2013. La diversidad de cultivos hortícolas. Pages 38-39 in M. J. Picó Garcés and M. Ruiz Brox, editors. Veus per l'horta. Universitat de València, Valencia, Spain.

Martín-López, B., I. Palomo, M. García-Llorente, I. IniestaArandia, A. J. Castro, D. García Del Amo, E. Gómez-Baggethun, and C. Montes. 2017. Delineating boundaries of social-ecological systems for landscape planning: a comprehensive spatial approach. Land Use Policy 66:90-104. https://doi.org/10.1016/j. landusepol.2017.04.040

Ministerio de Agricultura, Pesca y Alimentación. 2014. Encuesta sobre superficies y rendimientos cultivos (ESYRCE). Ministerio de Agricultura, Pesca y Alimentación, . [online] URL: https:// www.mapama.gob.es/es/estadistica/temas/estadisticas-agrarias/agricultura/ esyrce/
Muñoz Criado, A. 2009. Plan de la huerta de Valencia: un paisaje cultural milenario. Conselleria de Medi Ambient, Aigua, Urbanisme i Habitatge, Generalitat Valenciana, Valencia, Spain.

Murgui, E. 2010. Seasonal patterns of bird crop use in traditional irrigated land (the huerta of Valencia, Spain). Ardeola 57 (1):87-102. [online] URL: https://www.ardeola.org/en/volumes/571/ articles/87-102/

O'Connell, D., B. Walker, N. Abel, and N. Grigg. 2015. The resilience, adaptation and transformation assessment framework: from theory to application. CSIRO, Clayton, Australia. [online] URL: http://www.stapgef.org/sites/default/files/documents/CSIROSTAP-Resilience-Adaptation-Transformation-Assessment-FrameworkReport.pdf

Ortega-Reig, M., G. Palau-Salvador, M. J. Cascant i Sempere, J. Benitez-Buelga, D. Badiella, and P. Trawick. 2014. The integrated use of surface, ground and recycled waste water in adapting to drought in the traditional irrigation system of Valencia. Agricultural Water Management 133:55-64. https://doi. org/10.1016/j.agwat.2013.11.004

Pavón, D., F. Visentin, A. Ribas, and F. Vallerani. 2015. Multifuncionalidad y retos de futuro en el paisaje cultural del regadío del Bajo Ter. Pages 720-737 in C. Sanchis-Ibor, G. PalauSalvador, I. Mangue Alférez, and L. P. Martínez-Sanmartín, editors. Irrigation, society and landscape. Tribute to Tom F. Glick. Editorial Universitat Politècnica de València, Valencia, Spain. http://dx.doi.org/10.4995/ISL2014.2014.187

Piorr, A., I. Zasada, A. Doernberg, F. Zoll, and W. Ramme. 2018. Research for AGRI Committee - urban and peri-urban agriculture in the EU. Policy Department for Structural and Cohesion Policies, Brussels, Belgium. [online] URL: https://www.europarl. europa.eu/RegData/etudes/STUD/2018/617468/IPOL_STU(2018) 617468 EN.pdf

Plieninger, T., and C. Bieling. 2013. Resilience-based perspectives to guiding high-nature-value farmland through socioeconomic change. Ecology and Society 18(4):20. https://doi.org/10.5751/ ES-05877-180420

Plieninger, T., C. Hui, M. Gaertner, and L. Huntsinger. 2014. The impact of land abandonment on species richness and abundance in the Mediterranean basin: a meta-analysis. Plos One 9(5): e98355. https://doi.org/10.1371/journal.pone.0098355

Plieninger, T., T. Kizos, C. Bieling, L. Le Dû-Blayo, M.-A. Budniok, M. Bürgi, C. L. Crumley, G. Girod, P. Howard, J. Kolen, T. Kuemmerle, G. Milcinski, H. Palang, K. Trommler, and P. H. Verburg. 2015. Exploring ecosystem-change and society through a landscape lens: recent progress in European landscape research. Ecology and Society 20(2):5. https://doi.org/10.5751/ES-07443-200205

Quinlan, A. E., M. Berbés-Blázquez, L. J. Haider, and G. D. Peterson. 2016. Measuring and assessing resilience: broadening understanding through multiple disciplinary perspectives. Journal of Applied Ecology 53(3):677-687. https://doi.org/10.1111/1365-2664.12550

Sanchis Ibor, C. 2013. La dinámica histórica de l'horta. Page 21 in M. J. Picó Garcés and M. Ruiz Brox, editors. Veus per l'horta. Universitat de València, Valencia, Spain. 
Selman, P. 2012. Sustainable landscape planning: the reconnection agenda. Routledge, Abingdon, UK.

Shannon, C. E., and W. Weaver. 1964. The mathematical theory of communication. University of Illinois Press, Urbana, Illinois, USA.

Soulard, C.-T., E. Valette, C. Perrin, P. C. Abrantes, T. Anthopoulou, O. Benjaballah, S. Bouchemal, P. Dugué, M. El Amrani, S. Lardon, E. Marraccini, G. Mousselin, C. Napoleone, and J.-C. Paoli. 2018. Peri-urban agro-ecosystems in the Mediterranean: diversity, dynamics, and drivers. Regional Environmental Change 18:651-662. https://doi.org/10.1007/ $\underline{\text { s10113-017-1102-Z }}$

Stanners, D., and P. Bourdeau, editors. 1995. Europe's environment: the Dobris assessment. European Environment Agency, Copenhagen, Denmark. [online] URL: https://www.eea. europa.eu/publications/92-826-5409-5

Swanwick, C., and Land Use Consultants. 2002. Landscape character assessment: guidance for England and Scotland. Countryside Agency and Scottish Natural Heritage, Cheltenham and Edinburgh, UK. [online] URL: https://www.nature.scot/sites/ default/files/2018-02/Publication $\% 202002 \% 20-\% 20$ Landscape $\%$ 20Character $\% 20$ Assessment $\% 20$ guidance $\% 20$ for $\% 20$ England $\% 20$ and $\%$ 20Scotland.pdf

Universitat Politècnica de València and Ministerio de Agricultura Pesca y Alimentación. 2012. Evaluación de la Estrategia Nacional de los Programas Operativos Sostenibles a desarrollar por las Organizaciones de Productores de Frutas y Hortalizas. Technical Report.

Van Eetvelde, V., and M. Antrop. 2004. Analyzing structural and functional changes of traditional landscapes - two examples from southern France. Landscape and Urban Planning 67 (1-4):79-95. https://doi.org/10.1016/S0169-2046(03)00030-6

Van Eetvelde, V. and M. Antrop. 2007. Landscape character beyond landscape typology: methodological issues in transregional integration in Belgium. Pages 229-239 in 18th International annual ECLAS conference: Landscape assessment, from theory to practice: applications in planning and design. University of Belgrade, Belgrade, Serbia.

van Oudenhoven, F. J. W., D. Mijatović, and P. B. Eyzaguirre. 2011. Social-ecological indicators of resilience in agrarian and natural landscapes. Management of Environmental Quality 22 (2):154-173. https://doi.org/10.1108/14777831111113356

Walker, A. J., and R. L. Ryan. 2008. Place attachment and landscape preservation in rural New England: a Maine case study. Landscape and Urban Planning 86(2):141-152. https://doi. org/10.1016/j.landurbplan.2008.02.001

Wu, J. 2013. Landscape sustainability science: ecosystem services and human well-being in changing landscapes. Landscape Ecology 28:999-1023. https://doi.org/10.1007/s10980-013-9894-9 


\section{QUESTIONS FOR THE ASSESSMENT OF LANDSCAPE CHARACTER AREAS}

1. Write down the five landscape character areas you appreciate the most. Rank them.

2. Write down the five landscape character areas you visit with higher frequency. Rank them.

3. Write down the five landscape character areas you do not know or you have never visited. Rank them.
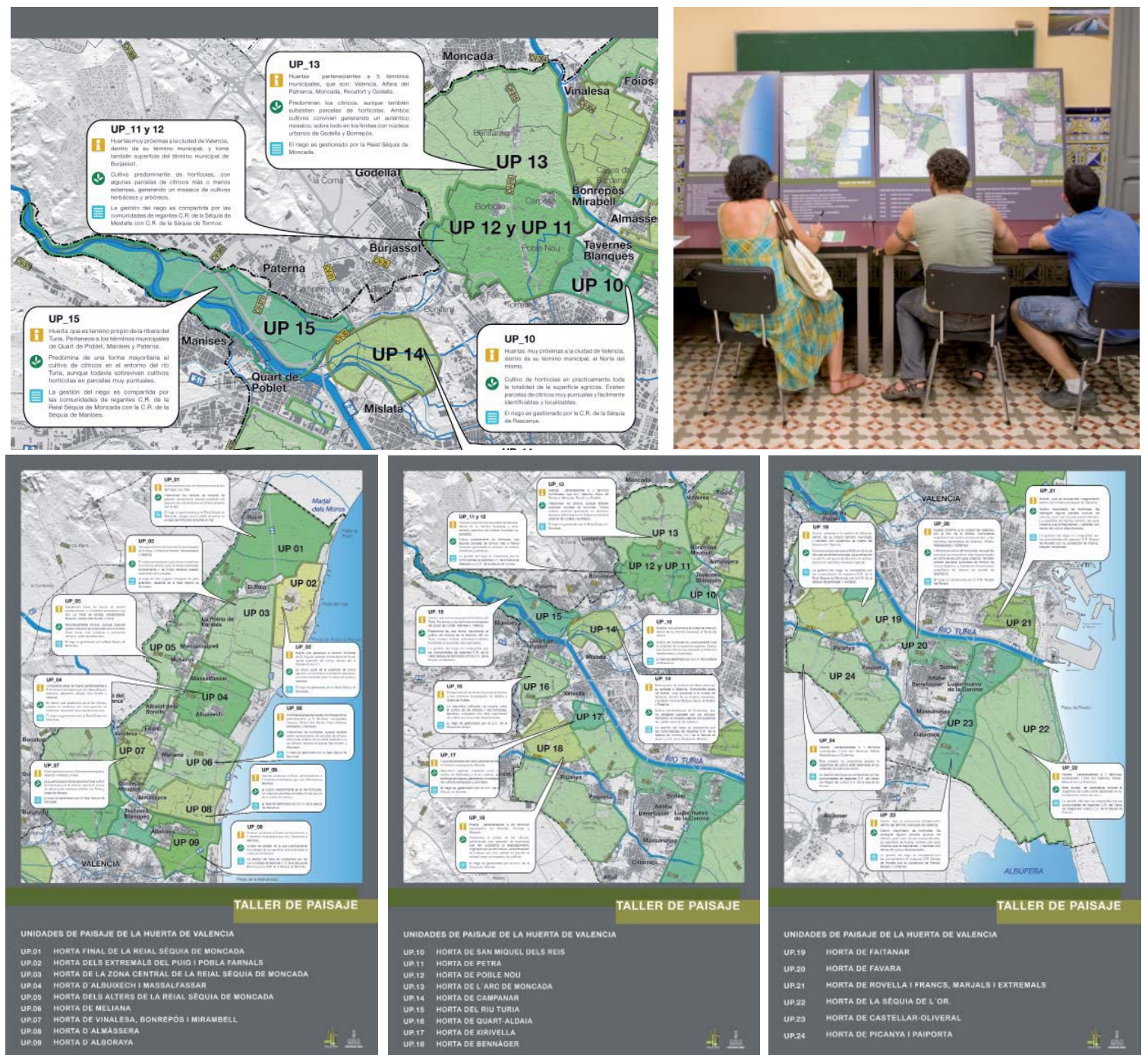

Images of the boards that were used to inform participants about the location and characteristics of landscape character areas. 
APPENDIX 2. Table of characterization of landscape character areas

\begin{tabular}{|c|c|c|c|c|c|c|c|c|c|c|c|c|c|c|c|}
\hline & 2008 & $(\%)$ & & & 2013( & & & & Diff & erence & between 2 & 2013 and & $018(\%)$ & & \\
\hline $\begin{array}{l}\mathrm{L}- \\
\mathrm{CA}\end{array}$ & Rice & $\begin{array}{l}\text { Citr- } \\
\text { us }\end{array}$ & $\begin{array}{l}\text { Herbac- } \\
\text { eous }\end{array}$ & $\begin{array}{l}\text { Aband- } \\
\text { oned }\end{array}$ & Rice & $\begin{array}{l}\text { Citr- } \\
\text { us }\end{array}$ & $\begin{array}{l}\text { Herba- } \\
\text { ceous }\end{array}$ & $\begin{array}{l}\text { Aban- } \\
\text { doned }\end{array}$ & $\begin{array}{l}\text { Ri- } \\
\text { ce }\end{array}$ & $\begin{array}{l}\text { Citr- } \\
\text { us }\end{array}$ & $\begin{array}{l}\text { Herbac- } \\
\text { eous }\end{array}$ & $\begin{array}{l}\text { Aband- } \\
\text { oned }\end{array}$ & $\begin{array}{l}\text { Rever- } \\
\text { sion }\end{array}$ & $\begin{array}{l}\text { Conver- } \\
\text { sion }\end{array}$ & $\begin{array}{l}\text { Positive } \\
\text { changes }\end{array}$ \\
\hline 1 & --- & 70.58 & 11.04 & 14.18 & --- & 65.87 & 10.07 & 17.38 & --- & -4.71 & -0.97 & 3.2 & 0.94 & 1.32 & 3.04 \\
\hline 2 & --- & 11.3 & 11.2 & 27.99 & --- & 9.38 & 9.23 & 26.37 & --- & -1.92 & -1.97 & -1.62 & 2.74 & 0.41 & 3.47 \\
\hline 3 & --- & 61.38 & 13.47 & 15.05 & --- & 48.99 & 10.74 & 25.1 & --- & $\begin{array}{l}-12 .- \\
39\end{array}$ & -2.73 & 10.05 & 1.16 & 0.29 & 4.61 \\
\hline 4 & --- & 53.53 & 33.59 & 9.13 & --- & 38.39 & 32.02 & 16.6 & --- & $\begin{array}{l}-15 .- \\
14\end{array}$ & -1.57 & 7.47 & 1.11 & 2.15 & 6.38 \\
\hline 5 & --- & 70.12 & 12.69 & 10.45 & --- & 57.3 & 11.19 & 21.28 & --- & $\begin{array}{l}-12 .- \\
82\end{array}$ & -1.5 & 10.83 & 0.52 & 1.4 & 3.65 \\
\hline 6 & --- & 22.26 & 70.64 & 2.92 & --- & 16.87 & 69.13 & 6.3 & --- & -5.39 & -1.51 & 3.38 & 0.32 & 0.65 & 2.7 \\
\hline 7 & --- & 44.89 & 47.75 & 3.99 & --- & 42.92 & 46.74 & 4.62 & --- & -1.97 & -1.01 & 0.63 & 0.75 & 1.4 & 3.27 \\
\hline 8 & --- & 4.27 & 90.42 & 1.33 & --- & 2.68 & 88.66 & 2.92 & --- & -1.59 & -1.76 & 1.59 & 0.04 & 0.74 & 0.79 \\
\hline 9 & --- & 0.47 & 89.15 & 3.49 & --- & 0.52 & 85.35 & 5.62 & --- & 0.05 & -3.8 & 2.13 & 0.06 & 0.01 & 0.28 \\
\hline 10 & --- & 0.91 & 89.48 & 1.01 & --- & 0.21 & 84.2 & 3.21 & --- & -0.7 & -5.28 & 2.2 & 0.27 & 0.0 & 1.32 \\
\hline 11 & --- & 20.83 & 71.12 & 3.02 & --- & 17.94 & 68.64 & 5.38 & --- & -2.89 & -2.48 & 2.36 & 0.0 & 1.11 & 1.11 \\
\hline 12 & --- & 14.55 & 75.39 & 3.22 & --- & 11.79 & 71.84 & 5.44 & --- & -2.76 & -3.55 & 2.22 & 0.85 & 2.4 & 5.21 \\
\hline 13 & --- & 47.18 & 41.97 & 6.18 & --- & 36.57 & 38.81 & 15.79 & --- & $\begin{array}{l}-10 .- \\
61\end{array}$ & -3.16 & 9.61 & 0.61 & 1.38 & 5.83 \\
\hline 14 & --- & 19.46 & 56.26 & 23.71 & --- & 11.8 & 52.44 & 25.78 & --- & -7.66 & -3.82 & 2.07 & 4.46 & 3.39 & 8.88 \\
\hline 15 & --- & 57.25 & 17.1 & 21.16 & --- & 32.27 & 15.45 & 34.81 & --- & $\begin{array}{l}-24 .- \\
98\end{array}$ & -1.65 & 13.65 & 3.55 & 1.59 & 10.05 \\
\hline 16 & --- & 24.12 & 28.55 & 31.19 & --- & 13.74 & 24.67 & 41.01 & --- & $\begin{array}{l}-10 .- \\
38\end{array}$ & -3.88 & 9.82 & 2.02 & 0.93 & 5.93 \\
\hline 17 & --- & 31.23 & 56.3 & 8.93 & --- & 26.12 & 53.41 & 11.62 & --- & -5.11 & -2.89 & 2.69 & 0.93 & 0.55 & 3.77 \\
\hline 18 & --- & 45.81 & 27.41 & 14.02 & --- & 27.23 & 24.89 & 20 & --- & $\begin{array}{l}-18 .- \\
58\end{array}$ & -2.52 & 5.98 & 2.1 & 5.88 & 13.65 \\
\hline 19 & --- & 30.17 & 36.21 & 16.8 & --- & 18.5 & 33.64 & 23.23 & --- & $\begin{array}{l}-11 .- \\
67\end{array}$ & -2.57 & 6.43 & 1.79 & 6.56 & 10.2 \\
\hline 20 & --- & 3.73 & 49.5 & 22.94 & --- & 1.88 & 44.58 & 25.27 & --- & -1.85 & -4.92 & 2.33 & 3.29 & 0.52 & 4.42 \\
\hline 21 & --- & 2.35 & 65.16 & 19.09 & --- & 1.6 & 60.13 & 20.1 & --- & -0.75 & -5.03 & 1.01 & 4.68 & 0.22 & 5.17 \\
\hline 22 & 90.81 & 0.7 & 2.34 & 4.04 & 90.80 & 0.64 & 2.24 & 3.61 & $\begin{array}{l}-0 .- \\
01\end{array}$ & -0.06 & -0.1 & -0.43 & 0.26 & 0.0 & 0.29 \\
\hline 23 & 11.2 & 16.46 & 48.49 & 13.6 & 11.02 & 11.56 & 45.17 & 16.01 & $\begin{array}{l}-0 .- \\
18\end{array}$ & -4.9 & -3.32 & 2.41 & 2.09 & 2.85 & 5.6 \\
\hline 24 & --- & 45.6 & 28.83 & 14.86 & --- & 28.15 & 25.47 & 23.22 & --- & $\begin{array}{l}-17 .- \\
45\end{array}$ & -3.36 & 8.36 & 2.58 & 9.09 & 12.26 \\
\hline $\begin{array}{l}\text { To- } \\
\text { tal }\end{array}$ & 15.76 & 32.24 & 32.59 & 11.11 & 15.75 & 25.00 & 34.49 & 15.52 & $\begin{array}{l}-0 .- \\
01\end{array}$ & -7.24 & 1.90 & 4.41 & 0.94 & 1.32 & 4.61 \\
\hline
\end{tabular}


APPENDIX 3. Cross tabulation for land use change in Huerta de Valencia during the period 2008-2013

\begin{tabular}{|c|c|c|c|c|c|c|c|c|c|c|c|c|c|c|c|c|}
\hline & LAN & JD US & E 2008 & (ha) & & & & & & & & & & & & \\
\hline $\begin{array}{l}\text { LAND } \\
\text { USE } 2013 \\
\text { (ha) }\end{array}$ & Rice & $\begin{array}{l}\text { Citr- } \\
\text { ical }\end{array}$ & $\begin{array}{l}\text { Cont- } \\
\text { ainers }\end{array}$ & $\begin{array}{l}\text { Hortic- } \\
\text { ultural }\end{array}$ & $\begin{array}{l}\text { Ind- } \\
\text { ustry }\end{array}$ & $\begin{array}{l}\text { Instal- } \\
\text { lation }\end{array}$ & $\begin{array}{l}\text { Green- } \\
\text { house }\end{array}$ & $\begin{array}{l}\text { Wet- } \\
\text { land }\end{array}$ & $\begin{array}{l}\text { Urb- } \\
\text { an } \\
\text { proc. }\end{array}$ & Palms & $\begin{array}{l}\text { Aban- } \\
\text { doned }\end{array}$ & $\begin{array}{l}\text { Stor- } \\
\text { age }\end{array}$ & $\begin{array}{l}\text { Asp- } \\
\text { halt- } \\
\text { ed }\end{array}$ & $\begin{array}{l}\text { Lan- } \\
\text { dfill }\end{array}$ & $\begin{array}{l}\text { Nur- } \\
\text { sery }\end{array}$ & $\begin{array}{l}\text { TOTAL } \\
2013\end{array}$ \\
\hline Rice & $\begin{array}{l}17- \\
90.5\end{array}$ & & & & & & & & & & 0.2 & & & & & 1790.7 \\
\hline & 99.- & & & & & & & & & & $0.01 \%$ & & & & & \\
\hline & $99 \%$ & & & & & & & & & & & & & & & \\
\hline Citrical & & $279-$ & & 31.6 & & & 0.2 & & & & 20.1 & & & & & 2843.1 \\
\hline & & 1.2 & & & & & & & & & & & & & & \\
\hline & & $\begin{array}{l}98.1- \\
7 \%\end{array}$ & & $1.11 \%$ & & & $0.01 \%$ & & & & $0.71 \%$ & & & & & \\
\hline Containers & & & 20.8 & & & & & & & & & & & & & 20.8 \\
\hline & & & $100 \%$ & & & & & & & & & & & & & \\
\hline Horticultural & 0.9 & 299.8 & & 3469.3 & & & 0.4 & & & 1.0 & 144.9 & & & 0.4 & 5.7 & 3922.4 \\
\hline & $\begin{array}{l}0.0- \\
2 \%\end{array}$ & $7.64 \%$ & & $88.45 \%$ & & & $0.01 \%$ & & & $0.03 \%$ & $3.69 \%$ & & & $0.01 \%$ & $0.15 \%$ & \\
\hline Industry & & 0.6 & & 1.7 & 182.1 & & & & & & 4.4 & & & 0.1 & 0.3 & 189.2 \\
\hline & & $0.32 \%$ & & $0.90 \%$ & $\begin{array}{l}96.2- \\
5 \%\end{array}$ & & & & & & $2.33 \%$ & & & $0.05 \%$ & $0.16 \%$ & \\
\hline Installation & & & & 0.6 & & 119.6 & & & 0.3 & & 0.2 & & & & & 120.7 \\
\hline & & & & $0.50 \%$ & & $99.09 \%$ & & & $0.25 \%$ & & $0.17 \%$ & & & & & \\
\hline Greenhouse & & & & 1.0 & & & 67.3 & & & & & & & & & 68.3 \\
\hline & & & & $1.46 \%$ & & & $98.54 \%$ & & & & & & & & & \\
\hline Wetland & & & & 5.6 & & & & 204.0 & & 0.4 & 11.6 & & & & & 221.6 \\
\hline & & & & $2.53 \%$ & & & & $\begin{array}{l}92.0- \\
6 \%\end{array}$ & & $0.18 \%$ & $5.23 \%$ & & & & & \\
\hline Urban & & 5.6 & & 5.6 & & & 0.1 & 1.6 & 60.5 & & 34.1 & 0.3 & & 0.4 & 4.0 & 112.2 \\
\hline & & $4.99 \%$ & & $4.99 \%$ & & & $0.09 \%$ & $1.43 \%$ & $\begin{array}{l}53.9- \\
2 \%\end{array}$ & & $30.39 \%$ & $0.27 \%$ & & $0.36 \%$ & $3.57 \%$ & \\
\hline Infrastruct- & & 7.2 & & 10.8 & & & & & 65.6 & & 5.5 & & & 1.1 & 0.4 & 90.6 \\
\hline & & $7.95 \%$ & & $11.92 \%$ & & & & & $\begin{array}{l}72.4- \\
1 \%\end{array}$ & & $6.07 \%$ & & & $1.21 \%$ & $0.44 \%$ & \\
\hline Palms & & 5.2 & & 3.9 & & & & & & 7.7 & 2.0 & & & & 0.8 & 19.6 \\
\hline & & $\begin{array}{l}26.5- \\
3 \%\end{array}$ & & $19.90 \%$ & & & & & & $\begin{array}{l}39.2- \\
9 \%\end{array}$ & $10.20 \%$ & & & & $4.08 \%$ & \\
\hline Abandoned & 0.6 & 538.4 & & 166.8 & 0.4 & & 2.5 & & 3.7 & 3.7 & 1038.8 & 0.5 & & 0.4 & 9.3 & 1765.1 \\
\hline & $\begin{array}{l}0.0- \\
3 \%\end{array}$ & $\begin{array}{l}30.5- \\
0 \%\end{array}$ & & $9.45 \%$ & $0.02 \%$ & & $0.14 \%$ & & $0.21 \%$ & $0.21 \%$ & $58.85 \%$ & $0.03 \%$ & & $0.02 \%$ & $0.53 \%$ & \\
\hline Storage & & 0.1 & & 0.3 & & & & & & & 0.2 & 33.1 & & & & 33.7 \\
\hline & & $0.30 \%$ & & $0.89 \%$ & & & & & & & $0.59 \%$ & $\begin{array}{l}98.2- \\
2 \%\end{array}$ & & & & \\
\hline Asphalted & & 0.5 & & & & & & & & & & & 2.0 & & & 2.5 \\
\hline & & $20.0-$ & & & & & & & & & & & $80.0-$ & & & \\
\hline & & $0 \%$ & & & & & & & & & & & $0 \%$ & & & \\
\hline Landfill & & & & & & & & & & & & & & $\begin{array}{l}46.8 \\
100 \%\end{array}$ & & 46.8 \\
\hline Nursery & & 3.8 & & 3.5 & & & & & & & & & & & 103.3 & 110.6 \\
\hline & & $3.44 \%$ & & $3.16 \%$ & & & & & & & & & & & $\begin{array}{l}93.4- \\
0 \%\end{array}$ & \\
\hline $\begin{array}{l}\text { Other fruit } \\
\text { trees }\end{array}$ & & 7.6 & & 5.4 & & & & & & & 1.1 & & & & & 14.1 \\
\hline
\end{tabular}




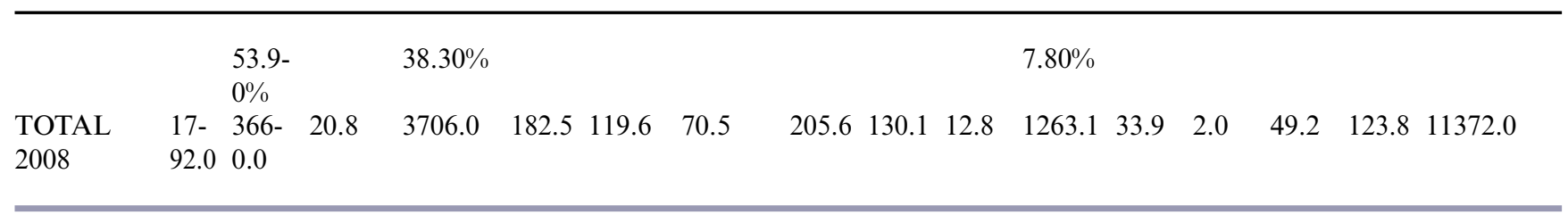


APPENDIX 4. Value of the indicators and factors linked to resilience referred to landscape character areas. Rate of abandonment in 2013 (Ab13), speed of abandonment (Aab), incidence of positive changes (Positive), percentage of reversion to arable land (Ab-hort), percentage of conversion to arable land (Citr-hort), rate of abandonment in 2008 (Ab08), percentage of herbaceous crops in 2008 (Hort08), percentage of citrus in 2008 (Citr08), percentage of rice in 2008 (Ric08), density of dwellings (Viv/ha), social use (Use), level of forgotten-ness (Forgot), social value (Value).

\begin{tabular}{|c|c|c|c|c|c|c|c|c|c|c|c|c|c|}
\hline \multirow[b]{2}{*}{$\begin{array}{l}\mathrm{L}- \\
\mathrm{CA}\end{array}$} & \multicolumn{2}{|c|}{$\begin{array}{l}\text { Persistence } \\
\text { indicators }\end{array}$} & \multicolumn{3}{|c|}{ Adaptability indicators } & \multicolumn{3}{|c|}{ Factors linked to resilience } & \multirow[b]{2}{*}{$\begin{array}{l}\text { Ric08 } \\
(\%)\end{array}$} & \multirow[b]{2}{*}{ Viv/ha } & \multirow[b]{2}{*}{ Use } & \multirow[b]{2}{*}{ Forgot } & \multirow[b]{2}{*}{ Value } \\
\hline & $\begin{array}{l}\text { Ab13 } \\
(\%)\end{array}$ & $\begin{array}{l}\text { Aab } \\
(\%)\end{array}$ & $\begin{array}{l}\text { Positive } \\
(\%)\end{array}$ & $\begin{array}{l}\text { Ab-Hort } \\
(\%)\end{array}$ & $\begin{array}{l}\text { Citr- } \\
\text { Hort } \\
(\%)\end{array}$ & $\begin{array}{l}\text { Ab08 } \\
(\%)\end{array}$ & $\begin{array}{l}\text { Hort08 } \\
(\%)\end{array}$ & $\begin{array}{l}\text { Citr08 } \\
(\%)\end{array}$ & & & & & \\
\hline 1 & 17.38 & 3.2 & 3.04 & 0.94 & 1.32 & 14.18 & 11.04 & 70.58 & --- & 1 & 1 & 1 & 1 \\
\hline 2 & 26.37 & -1.62 & 3.47 & 2.74 & 0.41 & 27.99 & 11.2 & 11.3 & --- & 2 & 1 & 1 & 1 \\
\hline 3 & 25.1 & 10.05 & 4.61 & 1.16 & 0.29 & 15.05 & 13.47 & 61.38 & --- & 1 & 1 & 1 & 1 \\
\hline 4 & 16.6 & 7.47 & 6.38 & 1.11 & 2.15 & 9.13 & 33.59 & 53.53 & --- & 2 & 1 & 1 & 1 \\
\hline 5 & 21.28 & 10.83 & 3.65 & 0.52 & 1.4 & 10.45 & 12.69 & 70.12 & --- & 2 & 1 & 1 & 1 \\
\hline 6 & 6.3 & 3.38 & 2.70 & 0.32 & 0.65 & 2.92 & 70.64 & 22.26 & --- & 3 & 3 & 1 & 3 \\
\hline 7 & 4.62 & 0.63 & 3.27 & 0.75 & 1.4 & 3.99 & 47.75 & 44.89 & --- & 2 & 2 & 1 & 2 \\
\hline 8 & 2.92 & 1.59 & 0.79 & 0.04 & 0.74 & 1.33 & 90.42 & 4.27 & --- & 4 & 3 & 1 & 3 \\
\hline 9 & 5.62 & 2.13 & 0.28 & 0.06 & 0.01 & 3.49 & 89.15 & 0.47 & --- & 4 & 3 & 1 & 3 \\
\hline 10 & 3.21 & 2.2 & 1.32 & 0.27 & 0.0 & 1.01 & 89.48 & 0.91 & --- & 3 & 1 & 1 & 1 \\
\hline 11 & 5.38 & 2.36 & 1.11 & 0.0 & 1.11 & 3.02 & 71.12 & 20.83 & --- & 3 & 1 & 1 & 2 \\
\hline 12 & 5.44 & 2.22 & 5.21 & 0.85 & 2.4 & 3.22 & 75.39 & 14.55 & --- & 3 & 2 & 1 & 3 \\
\hline 13 & 15.79 & 9.61 & 5.83 & 0.61 & 1.38 & 6.18 & 41.97 & 47.18 & --- & 2 & 3 & 1 & 2 \\
\hline 14 & 25.78 & 2.07 & 8.88 & 4.46 & 3.39 & 23.71 & 56.26 & 19.46 & --- & 2 & 1 & 1 & 1 \\
\hline 15 & 34.81 & 13.65 & 10.05 & 3.55 & 1.59 & 21.16 & 17.1 & 57.25 & --- & 2 & 2 & 2 & 1 \\
\hline 16 & 41.01 & 9.82 & 5.93 & 2.02 & 0.93 & 31.19 & 28.55 & 24.12 & --- & 1 & 1 & 3 & 1 \\
\hline 17 & 11.62 & 2.69 & 3.77 & 0.93 & 0.55 & 8.93 & 56.3 & 31.23 & --- & 2 & 1 & 3 & 1 \\
\hline 18 & 20 & 5.98 & 13.65 & 2.1 & 5.88 & 14.02 & 27.41 & 45.81 & --- & 2 & 1 & 3 & 1 \\
\hline 19 & 23.23 & 6.43 & 10.20 & 1.79 & 6.56 & 16.8 & 36.21 & 30.17 & --- & 2 & 1 & 3 & 1 \\
\hline 20 & 25.27 & 2.33 & 4.13 & 3.29 & 0.52 & 22.94 & 49.5 & 3.73 & --- & 2 & 1 & 2 & 1 \\
\hline 21 & 20.1 & 1.01 & 4.95 & 4.68 & 0.22 & 19.09 & 65.16 & 2.35 & --- & 4 & 1 & 2 & 1 \\
\hline 22 & 3.61 & -0.43 & 0.29 & 0.26 & 0.0 & 4.04 & 2.34 & 0.7 & 90.81 & 1 & 3 & 1 & 3 \\
\hline 23 & 16.01 & 2.41 & 5.76 & 2.09 & 2.85 & 13.6 & 48.49 & 16.46 & 11.2 & 2 & 2 & 2 & 2 \\
\hline 24 & 23.22 & 8.36 & 11.25 & 2.58 & 9.09 & 14.86 & 28.83 & 45.6 & --- & 2 & 2 & 1 & 2 \\
\hline
\end{tabular}


APPENDIX 5. Proportion of herbaceous crops in Huerta de Valencia (5a) and distribution of herbaceous crops in surface ranges (5b) in 2013
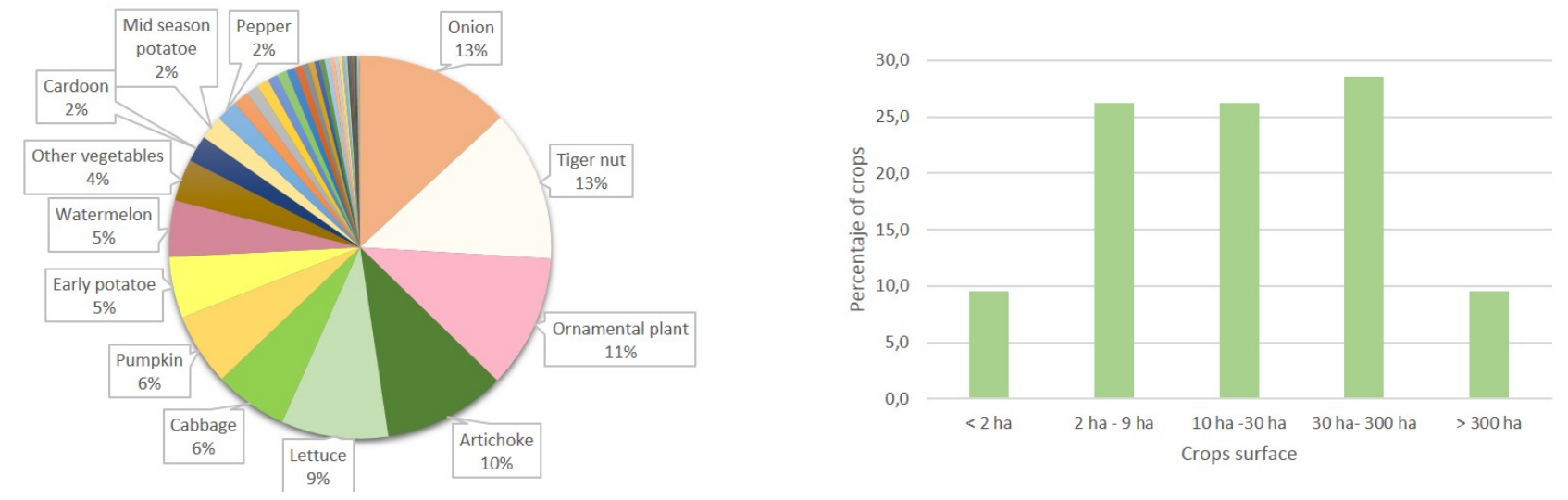
APPENDIX 6. Dwellings per hectare of the landscape character areas in Huerta de Valencia

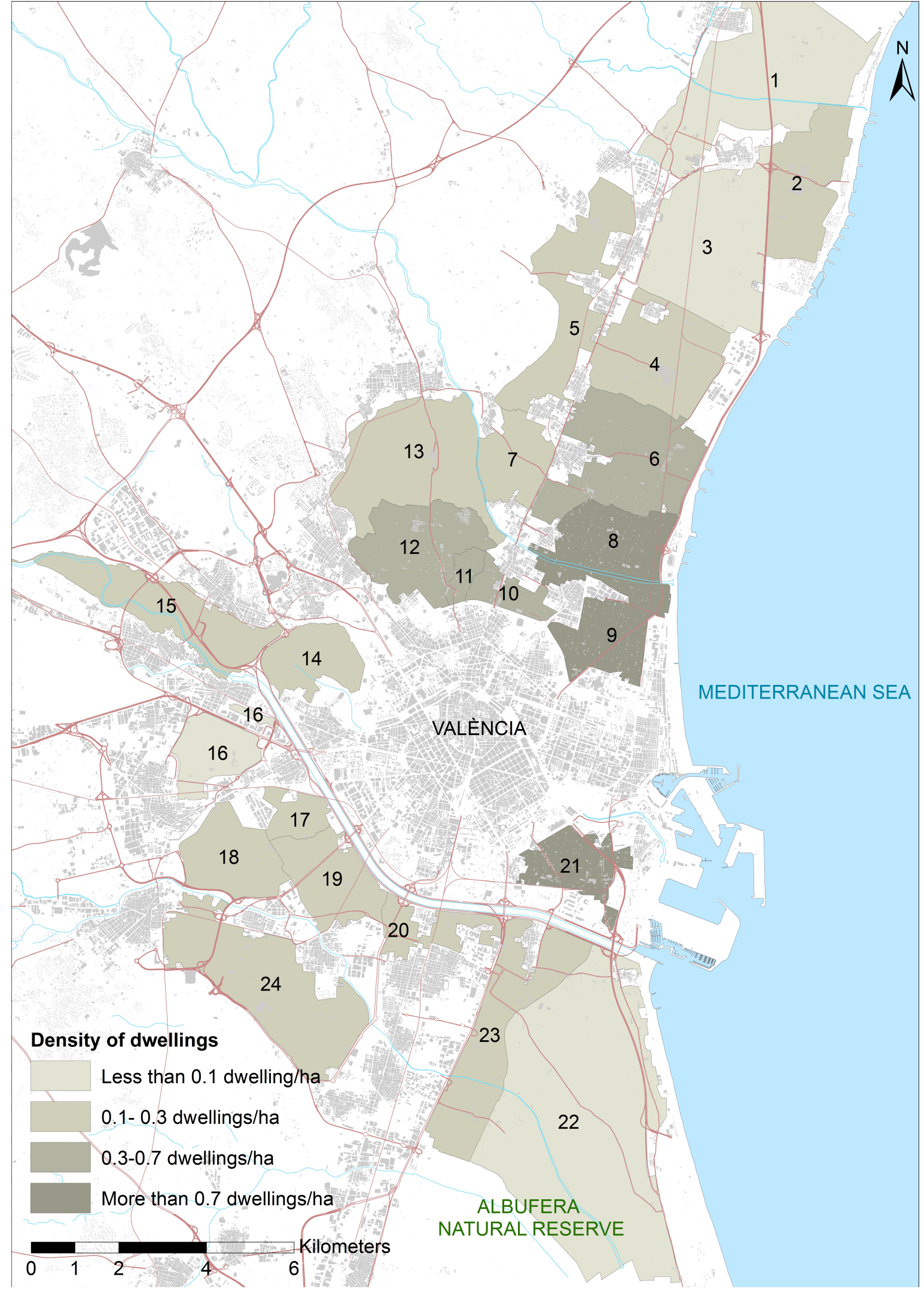

